\title{
AN EVALUATION OF THE POTENTIALITY OF EXOGENOUS OSMOPROTECTANTS MITIGATING WATER STRESS ON CHICKPEA
}

\author{
Kirti Bardhan ${ }^{1}$, V. Kumar ${ }^{2}$ and Dhimmar S.K. ${ }^{3}$
}

\begin{abstract}
Chickpea is grown mainly as a non-irrigated post rainy season crop, therefore, to increase the economic competitiveness of chickpea, the management of drought is essential. A practice which can be used to enhance drought tolerance in plants is osmotic adjustment besides stomatal control. A field experiment was carried out at the College Farm of Navsari Agricultural University, Navsari during rabi 2003-04 to evaluate the potentiality of chemical(s) which could be used to ameliorate water stress and compensate yield reduction in chickpea under unirrigated condition. During investigation four chemicals viz., Glycine betaine (10 ppm 20 ppm),

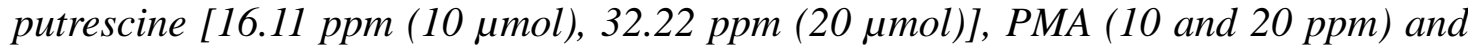
$\mathrm{KNO}_{3}$ (100 and $200 \mathrm{ppm}$ ) were evaluated along with water spray besides unirrigated and irrigated controls on two varieties of chickpea (GG-2 and Dahod Yellow). Aqueous solutions of chemicals were applied at 40 and 60 Days after sowing (DAS) on to the foliage. The results indicate that grain yield significantly declined due to water deficit. All foliar application of chemicals showed promising effect on crop health under unirrigated conditions. However, the significant effect was noticed with $\mathrm{KNO}_{3}(200 \mathrm{ppm})$. The plants following foliar application of $\mathrm{KNO}_{3}(200 \mathrm{ppm})$ attained significant increase in plant height, dry weight of plant, biomass, 100-seed weight and grain yield. For biomass it was found statistically equivalent to the irrigated control. Application of other chemicals was not as effective as $\mathrm{KNO}_{3}$ in alleviating stress. Glycine betaine showed significant improvement in dry weight and test weight yet it did not project potential yield of chickpea under unirrigated condition at Navsari.
\end{abstract}

Key Words: Chickpea, Drought tolerance, Osmotic adjustment, Stomatal control

\section{INTRODUCTION}

Chickpea is one of the most important legume cops of the country and of the semi-arid tropics. Yield losses due to drought in chickpea ranging between 20 and 50 per cent in important chickpea growing areas. One of the adoption mechanisms suggested for reducing vulnerability to drought is lowering of osmotic potential (Ludlow and Miuchow, 1990). Recently however spray of osmoprotectants has been proposed to enhance osmotic adjustment and improve drought tolerance which are highly soluble compatible compounds and serve to raise osmotic pressure in the cytoplasm when environment becomes unfavorable (Yancey, 1994). Glycine betaine is a quaternary ammonium compound accumulated by many species (Wyn Jones and Storey, 1981). Results from recent field and/or greenhouse experiments have shown promising effect on drought tolerance and crop growth through exogenous glycine betaine in spring cereals and summer turnip rape (Makale et al.1996), soybean (Agboma et al., 1997), tomato (Makela et al., 1998), cotton (Gorham and Jokinen, 1998) and kidney bean (Lopez et al., 2002). Other compound, the polymines also accumulated during stress and determined by the plant species

${ }^{3}$ Ph.D. Student (Agronomy) N.M. College of Agriculture, N.A.U., Navsari (Gujarat), India 
affected and the nature of stress (Rabe, 1990). The polyamines, spermine and spermidine are ubiquitously found in the plant kingdom together with their diamine precursor Putrescine (Smith, 1985). Higher levels of polyamines in stressed plants are of adoptive nature because of their role in the regulation of cellular ionic balance, maintenance of physical and chemical properties of membrane, prevention of chlorophyll ions and stimulation of synthesis of proteins and nucleic acids (Evans and Malimberg, 1989; Kumar et al., 1997). All naturally polyamines including spermidine, spermine, codavarine and putrescine strongly inhibited opening of stomata (Liu-Kun et al, 2000). Some of the results are well documented as on chickpea under salinity (Dhingra et al., 1997), maize under drought (Todorov-D et al., 1998) and on groundnut seedling (Vakharia et al., 2003), which suggest the possibility of foliar application of putrescine to mitigate the effect of water stress. In legumes, moisture stress has drastic effects on nitrogen fixation besides plant growth (Sinclair et al., 1987 and Serraj et al., 1999). Also the number of rhizobia in soil declines drastically as soil dries (Busshby and Marshall, 1997). Thus, foliar nitrogen nutrition may appear to mitigate this effect and increase drought tolerance. $\mathrm{KNO}_{3}$ may consider the best option because it also provides potassium which influences the water economy and crop growth, through its effect on water uptake, root growth, maintenance of turgour, transpiration and stomatal behaviour (Nelson, 1980, Hisao and Lauchli, 1986). Experimental evidence from chickpea suggests beneficial effects of $\mathrm{K}$ application under soil moisture deficit (Singh et al., 1997). However, potassium alone as a means of alleviating drought stress was found inefficient and appeared that the beneficial effect is due to stimulated growth rather than mitigating nitrogen deficiency (Kurdali et al., 2002).

As plants do not posses the ability to forecast the weather, artificial stomatal control may increase plant growth during moisture stress. Various field experiments are well documented in which antitranspriants were used as a management practice for drought e.g. chickpea (Gupta et al., 1991). Thus, our study addresses field test of the effect of exogenous application of these chemicals on growth and yield of chickpea with the objective to explore the possibility of compensating yield reduction due to restricted soil moisture by foliar application of suitable chemical/ chemicals.

\section{MATERIAL AND METHODS}

One year experiment was carried out during rabi season of the year 2003-04 with two cultivars of chickpea i.e., GG-2 and Dahod Yellow under unirrigated conditions. Plots of the experiment were demarcated in experimental area two meters away from adjacent field and irrigated control plots arranged two meters away from remaining plots in each replication to restrict moisture flow towards unirrigated plots. In this experiment, foliar spray of two concentration each of Glycine betaine (10 ppm $20 \mathrm{ppm})$, putrescine [16.11 ppm (10 $\mu \mathrm{mol}), \quad 32.22 \quad$ ppm (20 $\mu \mathrm{mol})]$, PMA (10 and $20 \mathrm{ppm}$ ) and $\mathrm{KNO}_{3}$ (100 and $200 \mathrm{ppm}$ ) and water spray, irrigated control, unirrigated control along with two varieties of chickpea made twenty two treatments of the experiment which were laid down in factorial randomized block design with three replications. The quantity of water for plot size was determined before the foliar application by spraying of water onto 
the foliage up to runoff point of the crop in a single plot. This practice was performed separately for two foliar sprays i.e. 40 and 60 DAS. The level of irrigation for irrigated control plot was determined by visual appearance i.e. slightly stagnant water for plot and applied through bucket at 40 and 60 DAS. One plot kept unsprayed and considered as unirrigated control plot. The potentiality of chemicals were assessed by observing growth parameters viz., periodical plant height and dry weight of plant, days to 50 per cent flowering and yield parameters viz., 100-seed weight, biomass, harvest index and grain yield. The observed data were analyzed statistically using analysis of variance at 5 per cent level of significance (Panse and Sukhatme, 1967).

\section{RESULTS AND DISCUSSION}

The data on growth parameters (Table1) indicated that difference in mean plant height and dry weight of plant at the time when the experimental treatments were first time applied (40 DAS), differences in irrigated control $\left(T_{11}\right)$ and other treatments $\left(T_{1}\right.$ to $\left.T_{10}\right)$ subjected to unirrigated condition were not significant. Afterwards, the results indicated significant reduction in plant height and dry weight of plant due to moisture deficit. These observations were similar to the findings of Bhattacharya et al. (1995) and Reddy and Ahlawat (1998). However, foliar application of $\mathrm{KNO}_{3}(200$ ppm) fairly compensated this reduction and showed significant increase over unirrigated control. This might be due to the fact that receding moisture which changes the plant water potential may cause a marked reduction in both the rate of nitrogen fixation and in the translocation of the products of nitrogen fixation to shoot as suggested by Rao and
Venkateswarlu (1987) and Venkateswarlu and Rao (1987) for mung. Also foliar nitrogen nutrition may influence water relation of plants (Radin and Parker, 1979). Here, nitrogen deficiency which may be caused by plant and/or soil factor was ameliorated by exogenous $\mathrm{KNO}_{3}$ application. The exogenous application of glycine betaine $(20 \mathrm{ppm})$ also recorded significantly increase in dry weight of plant over unirrigated control while it remained significantly lower than irrigated control. Glycine betaine may act on an antitranspirant which allowed the plant to access water for a longer period and facilitates more photosynthesis as reported by Agboma et al. (1997) in soybean above ground dry matter increment following foliar application of glycine betaine. All other exogenous applications were not promising. Also, none of the foliar applications significantly influenced days taken to 50 per cent flowering. However, $\mathrm{KNO}_{3}(200$ ppm) marginally delayed flowering. As chickpea being a long day plant, any delay in flowering would facilitate more dry matter production, so foliar application of $\mathrm{KNO}_{3}$ contributed in dry matter production (upto some extent) as indicated by delayed flowering also.

The data in Table 02 indicates the significance of various treatments on biomass (g/plant), 100 seed weight (g), harvest index (\%) and grain yield (kg/ha) for chickpea. Variety Dahod yellow was a higher yielder than GG-2 due to its higher biomass than GG-2 indicated by its higher dry matter synthesis during the course of development (Table 01) with higher partitioning efficiency. A significant reduction was recorded for the characters except harvest index. However, promising effect of foliar application on yield attributes were noticed under unirrigated conditions. A 
significant increase was observed in biomass and 100 seed weight with glycine betaine $(20 \mathrm{ppm})$ and $\mathrm{KNO}_{3}$ (100 and $200 \mathrm{ppm}$ ), yet the only foliar application of $200 \mathrm{pm} \mathrm{KNO}_{3}$ showed biomass, which was at par with the irrigated control. Interpretation of data on per cent basis revealed that reduction in biomass due to water deficit $\left(\mathrm{T}_{10}\right)$ was 28.0 per cent, whereas in $\mathrm{KNO}_{3} 200$ ppm $\left(\mathrm{T}_{8}\right)$ was 10.2 per cent, implying that 17.8 per cent reduction in biomass could be off sated by $\mathrm{KNO}_{3}$ (200 ppm) (Fig.-1). In normal situation nitrogen is translcoated from vegetative tissues to developing seeds, any limitation in nitrogen due to moisture stress during seed filling results in more rapid decline in canopy photosynthesis capacity thus limiting the potential productivity of legumes (Sinclair et al., 1987), $\mathrm{KNO}_{3}$ might have helped to tide over nitrogen limitation. The increased 100 seed weight following foliar application of glycine betaine to chickpea plant probably resulted from well known physiological function of endogenously synthesized glycine betaine. As a cytoplasmic osmoticum it enables the plant to maintain photosynthetic activity in osmotic stress conditions, stabilizes the enzymes, involves in amino acid metabolism and maintain turgour pressure (Wyn Jone and Storey, 1981). The foliar application of PMA and putrescine were not found to have significant influence on yield. The results from PMA application are in close agreement with the findings of Gupta et al. (1991). Foliar application of $\mathrm{KNO}_{3}$ compensated yield reduction in a promising manner. It recorded only 9.2 per cent reduction for 200 ppm and 13.4 per cent reduction for $100 \mathrm{ppm}$ compared to unirrigated control which recorded 20.4 per cent reduction over irrigated control (Figure 02). The increment of yield in soybean under drought stress by foliar application of $\mathrm{KNO}_{3}$ was also reported by Purcell and King (1996).

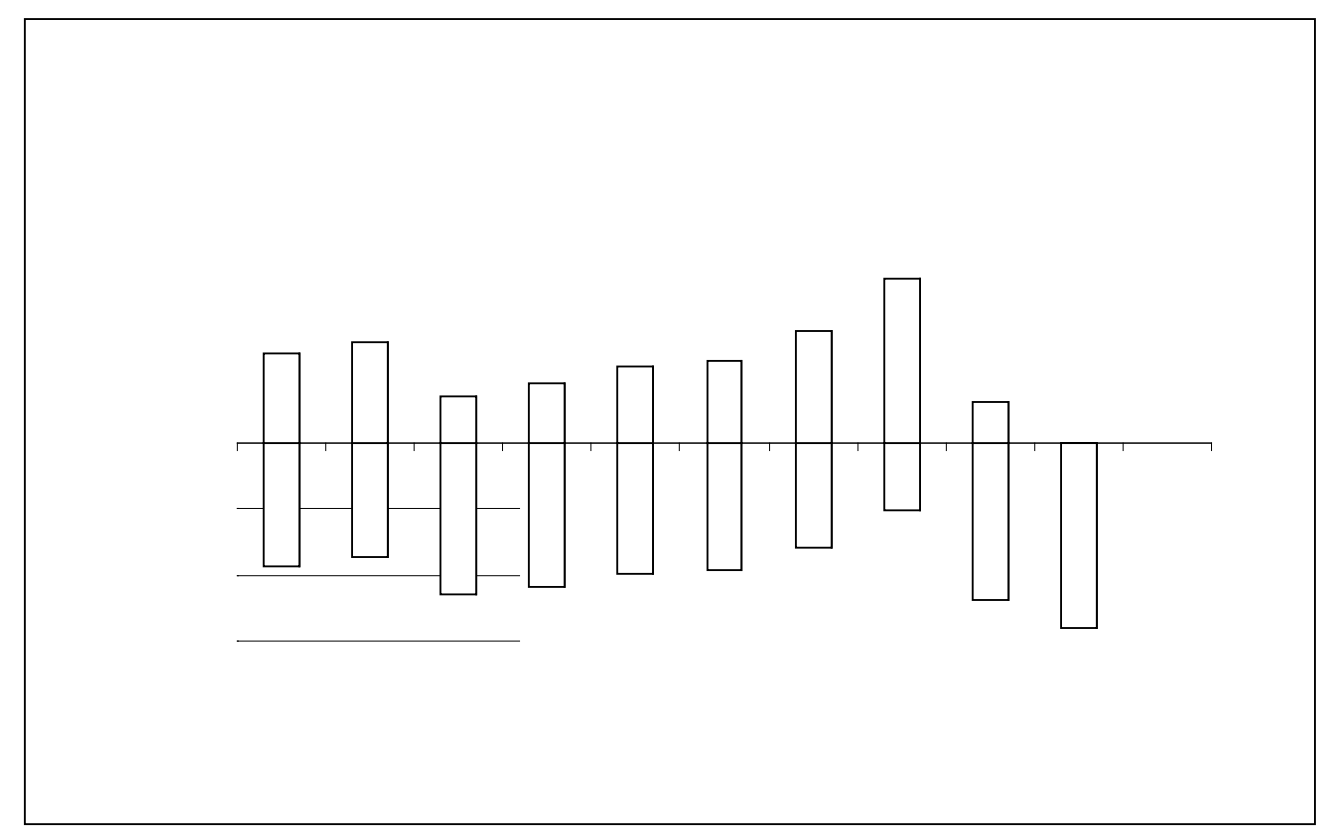


Table 01 : Effect of various chemicals on plant growth of chickpea under unirrigated conditions

\begin{tabular}{|c|c|c|c|c|c|c|c|}
\hline \multirow[t]{2}{*}{ Variety (V) } & \multicolumn{2}{|c|}{40 DAS } & \multicolumn{2}{|c|}{60 DAS } & \multicolumn{2}{|c|}{80 DAS } & \multirow{2}{*}{$\begin{array}{c}\text { Days to } \\
50 \% \\
\text { flowering }\end{array}$} \\
\hline & $\begin{array}{l}\text { Plant } \\
\text { height } \\
(\mathrm{cm})\end{array}$ & $\begin{array}{c}\text { Dry } \\
\text { weight } \\
\text { (g/plant) }\end{array}$ & $\begin{array}{l}\text { Plant } \\
\text { height } \\
(\mathrm{cm})\end{array}$ & $\begin{array}{c}\text { Dry weight } \\
\text { (g/plant) }\end{array}$ & $\begin{array}{l}\text { Plant } \\
\text { height } \\
(\mathrm{cm})\end{array}$ & $\begin{array}{c}\text { Dry } \\
\text { weight } \\
\text { (g/plant) }\end{array}$ & \\
\hline GG-2 & $29.6^{a}$ & $1.51^{a}$ & $38.5^{a}$ & $2.84^{b}$ & $46.3^{a}$ & $4.11^{b}$ & $42.8^{b}$ \\
\hline Dahod Yellow & $16.5^{b}$ & $0.82^{b}$ & $27.8^{b}$ & $4.19^{a}$ & $33.5^{b}$ & $7.59 \mathrm{a}$ & $55.1^{a}$ \\
\hline S.Em \pm & 0.4 & 0.02 & 0.5 & 0.07 & 0.6 & 0.12 & 0.7 \\
\hline C.D. $(p=0.05)$ & 1.3 & 0.07 & 1.3 & 0.19 & 1.8 & 0.34 & 2.1 \\
\hline \multicolumn{8}{|l|}{ Treatments $(T)$} \\
\hline $\mathrm{T}_{1}$ (Glycinebetaine $10 \mathrm{ppm}$ ) & 21.7 & 1.20 & $33.0^{b c}$ & $3.58^{c}$ & $39.6 \mathrm{bc}$ & $5.97^{\mathrm{bc}}$ & $46.2^{b}$ \\
\hline $\mathrm{T}_{2}$ (Glycinebetaine $20 \mathrm{ppm}$ ) & 23.6 & 1.23 & $33.7 \mathrm{bc}$ & $3.72^{c}$ & $40.5^{b c}$ & 6.05 bd & $46.7^{b}$ \\
\hline $\mathrm{T}_{3}$ (Putrescine $16.11 \mathrm{ppm}$ ) & 21.9 & 1.08 & $31.7^{b c}$ & $3.19^{b}$ & $38.0^{\mathrm{bc}}$ & $5.45^{b d}$ & $47.3^{b}$ \\
\hline $\mathrm{T}_{4}$ (Putrescine $32.22 \mathrm{ppm}$ ) & 22.4 & 1.10 & $32.2^{b c}$ & $3.28^{b}$ & $38.7 \mathrm{bc}$ & $5.60 \mathrm{bd}$ & $48.7^{b}$ \\
\hline $\mathrm{T}_{5}$ (PMA $\left.10 \mathrm{ppm}\right)$ & 23.1 & 1.19 & $33.1^{b c}$ & $3.55^{c}$ & $39.7^{b c}$ & 5.78 bd & $48.7^{b}$ \\
\hline $\mathrm{T}_{6}$ (PMA $20 \mathrm{ppm}$ ) & 23.2 & 1.10 & $33.2^{b c}$ & $3.35^{b c}$ & $39.9 \mathrm{bc}$ & 5.74 bd & $49.3^{b}$ \\
\hline $\mathrm{T}_{7}\left(\mathrm{KNO}_{3} 100 \mathrm{ppm}\right)$ & 23.6 & 1.23 & $33.7^{b c}$ & $3.75^{c}$ & $40.4^{b c}$ & $6.13^{a}$ & $49.5^{b}$ \\
\hline $\mathrm{T}_{8}\left(\mathrm{KNO}_{3} 200 \mathrm{ppm}\right)$ & 23.8 & 1.25 & $34.4^{c}$ & $3.82^{\mathrm{ac}}$ & $41.3^{c}$ & $6.30^{a}$ & $50.3^{b}$ \\
\hline T9 (Water spray) & 22.1 & 1.06 & $30.8^{b}$ & $3.11^{b}$ & $36.6^{b}$ & $5.30^{\mathrm{bd}}$ & $48.2^{b}$ \\
\hline $\mathrm{T}_{10}$ (Unirrigated control) & 22.1 & 1.06 & $30.7^{b}$ & $3.06^{b}$ & $36.5^{b}$ & $5.21^{b}$ & $45.3^{b}$ \\
\hline $\mathrm{T}_{11}$ (Irrigated control) & 25.3 & 1.27 & $38.4^{a}$ & $4.27^{\mathrm{a}}$ & $47.3^{a}$ & $6.86^{\mathrm{a}}$ & $58.5^{\mathrm{a}}$ \\
\hline S.Em \pm & 1.0 & 0.07 & 1.1 & 0.16 & 1.5 & 0.27 & 1.7 \\
\hline C.D. $(p=0.05)$ & NS & NS & 3.1 & 0.45 & 4.3 & 0.80 & 5.0 \\
\hline \multicolumn{8}{|l|}{ Interaction ( $\mathrm{V} \times \mathrm{T})$} \\
\hline $\mathrm{S} . \mathrm{Em} \pm$ & 1.5 & 0.08 & 1.5 & 0.22 & 2.1 & 0.38 & 2.4 \\
\hline C.D. $(p=0.05)$ & NS & NS & NS & NS & NS & NS & NS \\
\hline C.V. $\%$ & 11.1 & 11.4 & 8.0 & 10.8 & 9.2 & 11.37 & 8.5 \\
\hline
\end{tabular}

*Any two means having a common latter are not significantly different at 5 per cent level of significance (L.S.D.)

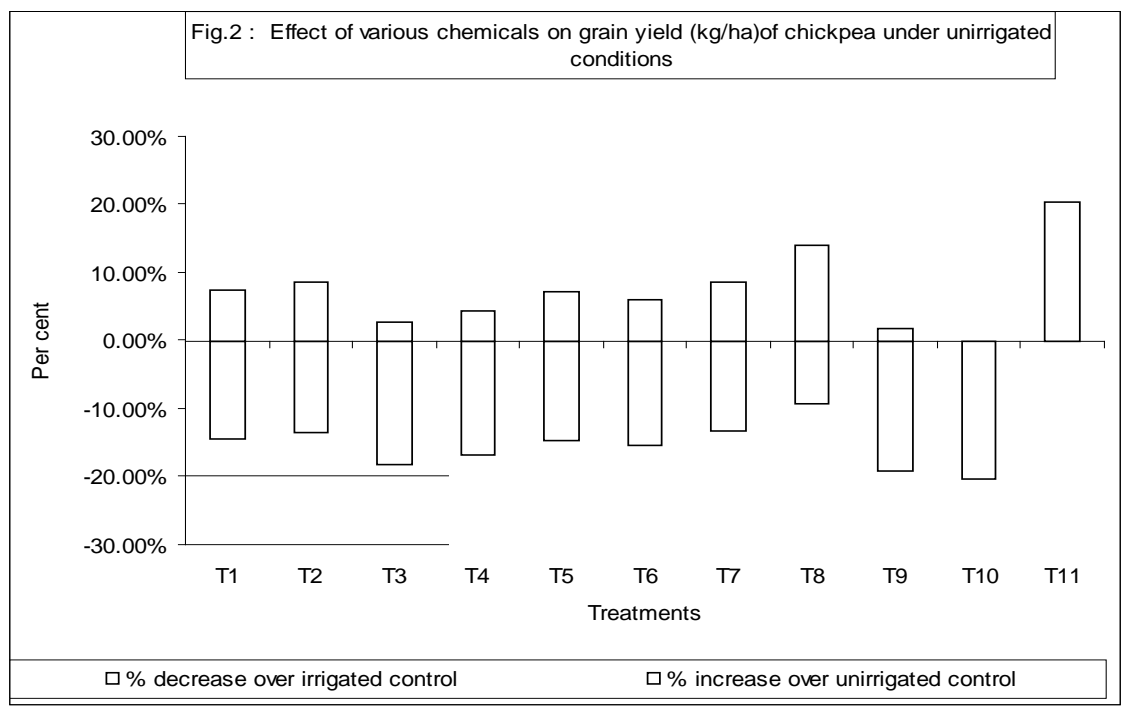

Figure 02: Effect of Various chemicals on grain yield (kg/ha)of chickpea under unirrigated condition 
Table 02: Effect of various chemicals on yield attributes of chickpea under unirrigated conditions

\begin{tabular}{|c|c|c|c|c|}
\hline Variety (V) & $\begin{array}{l}\text { 100-seed weight } \\
\text { (g) }\end{array}$ & $\begin{array}{c}\text { Biomass }(\mathrm{g}) / \\
\text { plant }\end{array}$ & $\begin{array}{l}\text { Harvest index } \\
(\%)\end{array}$ & $\begin{array}{c}\text { Grain yield } \\
\text { (kg/ha) }\end{array}$ \\
\hline GG-2 & $27.78^{a}$ & $11.6^{b}$ & $37.0^{\mathrm{b}}$ & $1008.2^{b}$ \\
\hline Dahod Yellow & $14.80^{b}$ & $14.2^{\mathrm{a}}$ & $42.9^{a}$ & $1082.2^{\mathrm{a}}$ \\
\hline S.Em \pm & 0.24 & 0.2 & 0.9 & 17.3 \\
\hline C.D. $(p=0.05)$ & 0.69 & 0.7 & 2.5 & 50.7 \\
\hline \multicolumn{5}{|l|}{ Treatments ( $T$ ) } \\
\hline $\mathrm{T}_{1}$ (Glycinebetaine $10 \mathrm{ppm}$ ) & $20.84^{\mathrm{bc}}$ & $12.8 \mathrm{bc}$ & 39.8 & $1040.7 \mathrm{bc}$ \\
\hline $\mathrm{T}_{2}$ (Glycinebetaine $20 \mathrm{ppm}$ ) & $21.02^{b c}$ & $13.0^{c}$ & 39.2 & $1052.4^{b c}$ \\
\hline $\mathrm{T}_{3}$ (Putrescine $16.11 \mathrm{ppm}$ ) & 20.36 bc & $12.1^{b}$ & 40.2 & 995.4 bc \\
\hline $\mathrm{T}_{4}$ (Putrescine $32.22 \mathrm{ppm}$ ) & $20.47^{b c}$ & $12.3^{b}$ & 40.2 & $1011.0^{b c}$ \\
\hline $\mathrm{T}_{5}$ (PMA $\left.10 \mathrm{ppm}\right)$ & $20.81^{b c}$ & $12.6^{b c}$ & 40.3 & $1038.5^{b c}$ \\
\hline $\mathrm{T}_{6}$ (PMA $\left.20 \mathrm{ppm}\right)$ & $20.74^{b c}$ & $12.7^{b c}$ & 40.3 & $1028.4^{b c}$ \\
\hline $\mathrm{T}_{7}\left(\mathrm{KNO}_{3} 100 \mathrm{ppm}\right)$ & $21.27^{c}$ & $13.2^{c}$ & 39.7 & $1054.0 \mathrm{bc}$ \\
\hline $\mathrm{T}_{8}\left(\mathrm{KNO}_{3} 200 \mathrm{ppm}\right)$ & $21.74^{c}$ & $14.1^{\mathrm{ac}}$ & 39.2 & $1104.6^{a c}$ \\
\hline $\mathrm{T}_{9}$ (Water spray) & $20.03^{b}$ & $12.0^{b}$ & 40.2 & $985.3^{b}$ \\
\hline $\mathrm{T}_{10}$ (Unirrigated control) & $19.25^{b}$ & $11.3^{b}$ & 42.1 & $969.3^{b}$ \\
\hline $\mathrm{T}_{11}$ (Irrigated control) & $26.69^{a}$ & $15.7^{a}$ & 28.8 & $1217.1^{\mathrm{a}}$ \\
\hline $\mathrm{S} . \mathrm{Em} \pm$ & 0.55 & 0.5 & 2.0 & 40.5 \\
\hline C.D. $(p=0.05)$ & 1.62 & 1.6 & NS & 118.8 \\
\hline \multicolumn{5}{|l|}{ Interaction (V x T) } \\
\hline $\mathrm{S} . \mathrm{Em} \pm$ & 0.78 & 0.7 & 2.9 & 57.3 \\
\hline C.D. $(p=0.05)$ & NS & NS & NS & NS \\
\hline C.V. $\%$ & 6.34 & 10.1 & 12.5 & 9.5 \\
\hline
\end{tabular}

*Any two means having a common latter are not significantly different at 5 per cent level of significance (L.S.D.)

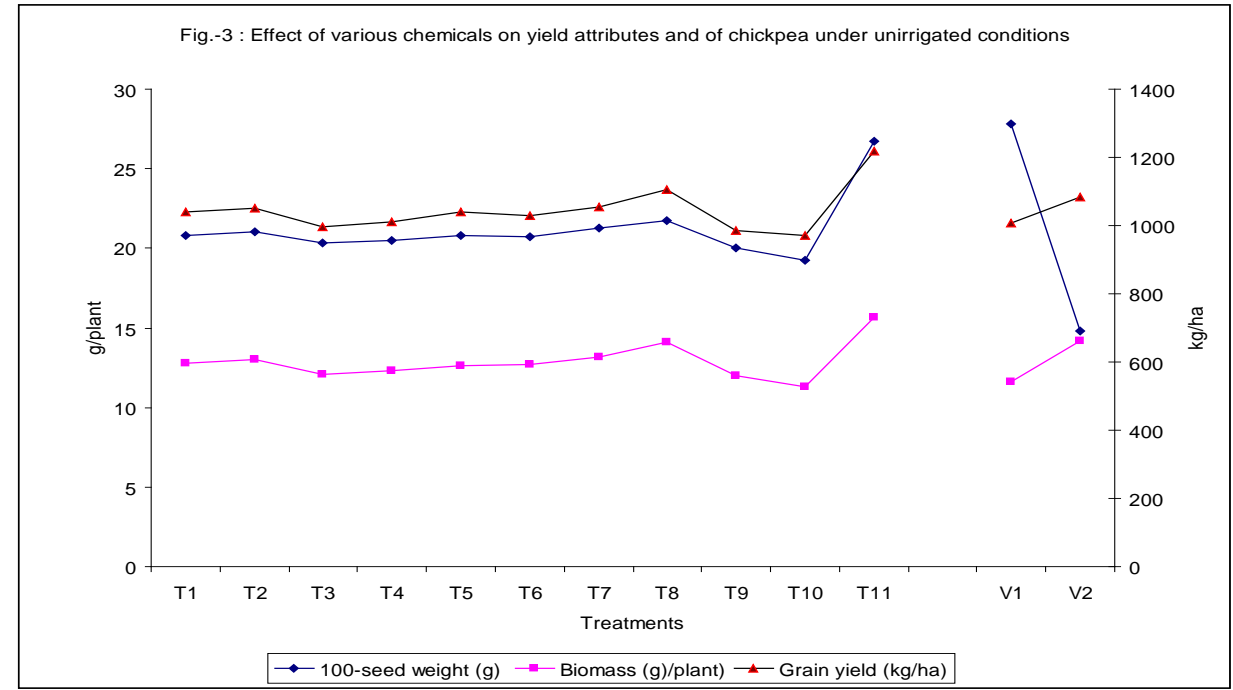

Figure 03: Effect of various chemicals on yield attributes of chickpea under unirrigated conditions 


\section{CONCLUSION}

Among the various chemicals which were applied to alleviate the reduction in yield of chickpea caused by water deficit, foliar application of $\mathrm{KNO}_{3}$ (200 ppm) at 40 and 60 DAS showed promising effect on growth and found most effective osmoprotectants in compensating yield losses. However, the results of present investigation indicated that glycine betaine and putrescine showed no actual potential at Navsari for the chickpea yield but further studies are needed in stress prone environment before discarding their potentiality for preventing crop failures.

\section{References :}

Agboma, P.C., T.R.Sinclair, , K.Jokinen, , P.P. Sainio, and E. Pehu, (1997). An evaluation of the effect of exogenous glycinebetaine on the growth and yield of soybean : timing of application watering regimes and cultivars. Field Crop Research, 54 : pp.51-64.

Bhattachrya, A., D.N. Singh, and RajDesh (1995). Association of yield and yield components under soil moisture stress and non stress condition in chickpea. Legume Research, 18 (4) : pp.193-199.

Bushby, H.V.A. and K.C. Marshall, (1977). Water status of rhizobia in relation to their susceptibility to desiccation and to their protection by montmorrillonite. $J$. Gen. Microbiology, 99 : pp.19-27.

Dhingra, H.R., M.Sharma, and T.M. Varghese, (1997). Role of putrescine in amelioration of salinity effects on reproductive parameters of chickpea (Cicer arietinum L.). Indian J. Plant Physiol., 2 (2) : pp160-162.

Evans, P.T. and R.L. Malimberg, (1989). Do polyamines have roles in plant development?. Ann. Rev. Plant Physiol. Mol. Biol., 40 : pp235-269.

Gorham, J. and K. Jokinen, (1998). Glycinebetaine treatment improves cotton yields in field traits in Pakistan. Abstracts, World Cotton Research Conference II, Athens, Greece, August. 1998, pp. 329.

Gupta, I.N., P.L Maliwal, and S.S. Rathore, (1991). Effect of phenyl mercuric acatate spray on yield and economics of different winter crops under receding soil moisture condition. Indian J. of Agricultural Sci., 61 (6) : pp.429-430.

Hsiao, T.C. and A. Lauchli, (1986). Role of potassium in plant water relations In Tinker, B. and Lauchli, A. (eds.). Advances in Plant Nutrition, 2 : pp281-312, Prager, New York.

Kumar, A., T.Altabella, M.A. Taylor, and A.F. Tiburcio, (1997). Recent advances in polyamine research trends. Plant Sci., 2 : pp124-130.

Kurdali, F., Farid Al Ain and Shamma, Al. M. (2002). Nodulation, dry matter production and nitrogen fixation by faba bean and chickpea as affected by soil moisture and potassium fertilizer. J. Plant Nutrition, 25 (2) : pp355-368.

Liu-Kun; Fu-HuiHua; Bei-Qixin; Laun-Sheng; Liu-K; Fu, H.H.; Bei-QX and Luan, S. (2000). Inward potassium channel in guard cells as a target for polyamine regulation of stomatal movements. Plant Physiol., 124 (3) : pp1315-1325.

Lopez, C.M.L.; H. Takahashi, and S. Yamazaki, (2002). Plant water relations of kidney bean plants treated with $\mathrm{NaCl}$ and foliarly applied Glycinebetaine. $J$. Agron.. Crop Sci., 188 : pp73-80.

Ludlow, M.M. and R.C. Muchiow, (1990). A critical evaluation of the traits for improving crop yield in water limited environment. Adv. Agron., 43 : pp107153. 
Makela, P., J.Mantila, R. Hinkkanen, E. Pehu, and P.P. Saino, (1996). Effect of foliar application of glycinebetaine on stress tolerance, growth and yield of spring cereals and summer turnip rape in Finland. J. Agron. and Crop Science, 176 : pp.223-234.

Makela, P., R. Munns, T.D. Clomer, A.G. Condon, and P.P. Sainio, (1998). Effect of foliar application of glycinebetaine on stomatal conductance, abscisic acid and solute concentration in leaves of salt and drought stressed tomato. Aust. J. Pl. Physiol., 25 : p.663.

Nelson, W.L. (1980). Interactions of potassium with moistures and temperature. In : Potassium in Agriculture (Ed.) Nelson, W.L. pp. 109-112. Potash and Phosphate inst., Atlanta, USA.

Panse, V.G. and P.V. Sukhatme, (1967). "Statistical methods for Agricultural Workers". ICAR, New Delhi.

Purcell, L.C. and C.A. King, (1996). Drought and nitrogen source effects on nitrogen nutrition, seed growth and yield in soybean. J. Pl. Nutr., 19 (6) : pp.969-993.

Rabe, E. (1990). Stress physiology : The functional significance of the accumulation of nitrogen containing compounds. J. Hort. Sci., 65 : pp.231-243.

Radin, J.W. and L.L. Parker, (1979). Water relations of cotton plants under nitrogen deficiency. Plant Physiol., 64 : pp.499-501.

Rao, A.V. and B. Venkateswarlu, (1987). Nitrogen fixation as influenced by water stress in selected crop legumes of the Indian arid zones. Arid Soil Research and Rehabilitation, 1 : pp.89-96.

Reddy, N.R.N. and I.P.S. Ahlawat, (1998). Response of chickpea (Cicer arietinum L.) genotypes to irrigation and fertilizer under late sown conditions. Indian $J$. Agron., 43 (1) : pp.95-101.

Serraj, R. T.R. Sinclair, and L.C. Purcell, (1999). Symbiotic $\mathrm{N}_{2}$ fixation response to drought. J. Experimental Botany, 50 : pp.143-155.

Sinclair, T.R., R.C. Muchow,; M.M. Ludlow, G.J. Leach, R.J. Lawan, and M.A. Foale, (1987). Field and model analysis of the effect of water deficits on carbon and nitrogen accumulation by soybean, cowpea and blackgram. Field Crop Res., $17:$ pp121-140.

Singh, N., V. Chhokar, K. D. Sharma, and M. S. Kuhad, (1997). Effect of potassium on water relations, $\mathrm{CO}_{2}$ exchange and plant growth under quantified water stress in chickpea. Indian J. Plant Physiol., 12(3):pp.202-206

Smith, T.A. (1985). Polymines. Ann Rev of Plant Physiology, 36 : 117-143.

Todorov, D., V. Alexieva, and E. Karanov, (1998). Effect of putrescine, 4-PU-30, and abscisic acid on maize plants growth under normal, drought and rewatering conditions. J. of Plant Growth Regulation, 17 (4) : pp.197-203.

Vakharia, D.N.; A.D. Kukadia, and M. Parameshwaran, (2003). Polyamines in response to artificial water stress in groundnut seedlings. Indian $\mathrm{J}$. Pl. Physiol., 8 (4) : pp.383-387.

Venkateswarlu, B. and A.V. Rao, (1987). Quantitative effects of field water deficits on $\mathrm{N}_{2}\left(\mathrm{C}_{2} \mathrm{H}_{2}\right)$ fixation in selected legumes grown in the Indian desert. Biology and Fertility of Soils, 5 : pp.18-22.

Wyn Jones, R.G. and R. Storey, (1981). Betains In Peleg, L.G. and Aspinall, D. (Eds.). The Physiology and Biochemistry of drought resistance in plants. Academic press, Sydney, pp. 171-204.

Yancey, P.H. (1994). Compatible and counteracting solutes. In K. Strange (eds.) : Cellular and Molecular physiology of cell volume Regulation, CRC Press, Boca ration, FL. 81-109. 